\title{
Rapid and Reliable Determination of Glipizide in Pharmaceutical Samples by HPLC and Its Degradation Study
}

\author{
Basavaiah $\mathrm{K}^{1 *}$ and Rajendraprasad $\mathbf{N}^{2}$ \\ ${ }^{1}$ Department of Chemistry, University of Mysore, \\ Manasagangothri, Mysuru-570 006, Karnataka, India \\ ${ }^{2}$ PG Department of Chemistry, J SS College of Arts, \\ Commerce \& Science, B N Road, Mysuru-570 025, \\ Karnataka, India \\ *Corresponding author: Basavaiah K, Department \\ of Chemistry, University of Mysore, Manasagangothri, \\ Mysuru-570 006, Karnataka, India
}

Received: J anuary 08, 2017; Accepted: February 08, 2017; Published: February 10, 2017

\begin{abstract}
A simple, specific and rapid high-performance liquid chromatographic (HPLC) method for the determination of glipizide (GPZ) in pharmaceutical sample is described. Reversed phase chromatography was performed on an Inertsil ODS $3 \mathrm{~V}(150 \times 4.6 \mathrm{~mm} ; 5 \mu \mathrm{m}$ particle size $)$ column with an isocratic mobile phase consisting of $10 \mathrm{mM}$ potassium dihydrogen phosphate $(\mathrm{pH} 3.9)$ and methanol $(60: 40 \mathrm{v} / \mathrm{v})$. The effluent was monitored on a uv detector at $220 \mathrm{~nm}$ and the column temperature was maintained at $35^{\circ} \mathrm{C}$. Linear response $(r=0.9999)$ was observed over the range, $1-450 \mathrm{gmLL}^{-1}$; and the limits of detection (LOD) and quantification (LOQ) were calculated to be 0.03 and $0.09 \mathrm{\mu gmL}^{-1}$, respectively. Both intra-day and inter-day precisions at three tested concentrations were excellent, with \%RSD values of $<1 \%$ and the accuracy was better than $1.5 \%$ (RE). The method was also validated for robustness, ruggedness and selectivity and the results were satisfactory. The method was applied to the determination of GPZ in tablets and the results agreed well with the label claim and those obtained by European Pharmacopeial method. Entire assay was complete in less than 10min. As part of degradation study, the drug was subjected to acid-, base-, peroxide-, heat-, and light-induced stress conditions, and the drug was found to be susceptible to degradation under oxidation, and inert to other conditions.
\end{abstract}

Keywords: Glipizide; Determination; HPLC; Pharmaceuticals; Stabilityindicating

\section{Introduction}

Glipizide

(GPZ),

chemically

known

as $N$-[2[4[[[(cyclohexylamino)carbonyl]amino] sulfonyl] phenyl] ethyl]-5- methylpyrazinecarboxamide (Figure 1) is an oral antihyper glycaemic agent [1]. It belongs to sulphonyl-urea class of anti-diabetics, which are indicated for type-2 diabetes mellitus [2]. The drug functions by stimulating the pancreas to release insulin by closing the ATP-dependent potassium channels in the $\beta$-cell membrane, which leads to an opening of the calcium channels. The resulting influx of calcium induces insulin secretion.

Owing to its therapeuticimportance different methods are available for determination of GPZ in body fluids and include, HPLC [3-11], LC-MS/MS [12-16], UPLC-MS/MS [17,18] and radioimmunoassay [19]. European Pharmacopeia [20] describes a titrimetric assay in which drug in dimethyl formamide is titrated with lithium methoxide using quinaldine red as indicator. Methods based on numerous other techniques have been suggested for the determination of GPZ in pharmaceuticals including, uv-spectrophotometry [21-24], UPLC [25,26], TLC [27,28], HPTLC [29] and voltammetry [30].

HPLC offers many advantages over other techniques, including minimum sample manipulation prior to chromatography, rapid analysis, and simultaneous determination of multiple compounds with good accuracy, precision and selectivity. Literature survey revealed the availability of few HPLC methods for GPZ. An RP-HPLC method was described by Vijaya et al [31] for the determination of GPZ in dosage forms using $\mathrm{C}_{18}$ column $(250 \times 4.6 \mathrm{~mm} ; 5 \mu \mathrm{m})$. The mobile phase consisted of methanol- triethylamine buffer, $\mathrm{pH} 3$ (35: 65) with a flow rate of $1 \mathrm{mLmin}^{-1}$ and UV- detection at $230 \mathrm{~nm}$. Linearity was found in the range, $0.1-10 \mu \mathrm{gmL}^{-1}$. Mantri and Shanmukhappa [32] developed and validated an RP-HPLC method with $\mathrm{C}_{18}$ analytical column using methanol- $0.115 \% \mathrm{w} / \mathrm{v}$ ammonium hydrogenphosphate buffer pumped at $1 \mathrm{mLmin}-1$ at ambient temperature. The calibration graph was linear in the range of 10-70 $\mu \mathrm{g} \mathrm{mL} L^{-1}$. Rapid and sensitive assay of GPZ was achieved by Rahila and Asif [33]. The drug was chromatographed on a RP- $\mathrm{C}_{18}$ column with mobile phase consisting of $0.05 \mathrm{M} \mathrm{KH}_{2} \mathrm{PO}_{4}, \mathrm{pH}$ 7.0- methanol (15: 85 $\mathrm{v} / \mathrm{v})$ pumped at a flow rate of $1 \mathrm{mLmin}^{-1}$. Quantification was achieved by monitoring the UV absorbance at $225 \mathrm{~nm}$. The method showed linearity in the range $10-2000 \mathrm{ngmL}^{-1}$. An Inertsil ODS- $\mathrm{C}_{18}$ column $(250 \times 4.6 \mathrm{~mm} ; 5 \mu \mathrm{m})$ in isocratic mode with mobile phase containing methanol- water- $0.01 \mathrm{M} \mathrm{KH}_{2} \mathrm{PO}_{4},(70: 25: 5 \mathrm{v} / \mathrm{v} / \mathrm{v})$ at a flow rate of

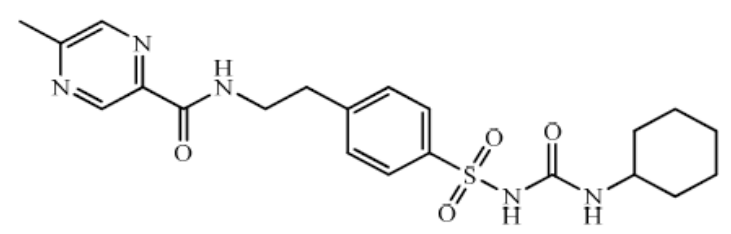

Figure 1: Structure of GPZ.
Austin J Anal Pharm Chem - Volume 4 Issue 1 - 2017 ISSN : 2381-8913 | www.austinpublishing group.com Basavaiah et al. () All rights are reserved
Citation: Basavaiah K and Rajendraprasad N. Rapid and Reliable Determination of Glipizide in Pharmaceutical Samples by HPLC and Its Degradation Study. Austin J Anal Pharm Chem. 2017; 4(1): 1080. 
$1.5 \mathrm{mLmin}^{-1}$ and UV- detection at $270 \mathrm{~nm}$ was used by Rayanam et al [34] for the assay of GPZ in tablet formulation. The method has been found to be sensitive with LOD and LOQ values of 15 and 45 $\mu \mathrm{gmL}^{-1}$, respectively. The method was also applied for blood serum. Determination of GPZ in sustainedrelease tablets by RP-HPLC has been reported by Liping et al. [35] Separation and assay were carried out on an Eclipse XDB- $\mathrm{C}_{18}$ column with $0.1 \mathrm{M} \mathrm{NaH} \mathrm{PO}_{4}$-methanol (54: 46) as mobile phase pumped at a flow rate of $1 \mathrm{mLmin}^{-1}$ and UV detection at $225 \mathrm{~nm}$. The linear range was from 5 to $250 \mu \mathrm{gmL}^{-1} \mathrm{GPZ}$.

Apart from the above methods for GPZ in single component dosage forms,several workers have applied HPLC for the simultaneous determination of GPZ inmulti-component dosage forms when the drug is present along with glimepiride [36], metformin [37-39], simvastatin [40], pioglitazone and rosiglitazone [41], rosiglitazone, pioglitazone, glibenclamide andglimepiride [42], metformin, pioglitazone, glimeperide, gliclazide andglibenclamide [43], metformin, pioglitazone, phenformin, gliclazide, glimeperide,gl ibenclamidetolbutamide, rosiglitazone and pioglitazone [44].

The reported HPLC methods for single component tablets [31-35] suffer from low detection limits and narrow linear dynamic ranges of applicability, and none of them is stability-indicating. The stability study should be undertaken to elucidate the intrinsic stability of the drug substance. Stability testing of a drug substance should be carried out under different stress conditions, such as hydrolysis, oxidation, heat and light to evaluate the stability-indicating supremacy of an analytical method used for assay $[45,46]$. Driven by the need for an HPLC method, which is sensitive with a wide linear dynamic range, and also stability-indicating, this study was taken up. This work describes the development and validation of a rapid and reliable HPLC method for the determination of GPZ in bulk drug and tablets containing only GPZ (single-component). The method was found to be stability indicating.

\section{Materials and Methods}

\section{Instrument and software}

Chromatographic analysis was performed with a Waters HPLC system (Waters Corporation, Milford, USA) equipped with Alliances 2695 series low pressure quaternary gradient pump, a programmable variable wavelength UV detector and auto sampler. Data were collected and processed using Waters Empower 2 software.

\section{Reagents}

HPLC grade methanol was purchased from Merck, Mumbai, India; potassium dihydrogen orthophosphate, triethylamine, orthophosphoricacid, hydrochloric acid, sodium hydroxide and hydrogen peroxide were from Qualigens Ltd., India. Water purified by the Milli-Q system (Millipore, Milford, Massachusetts, USA) was used to prepare mobile phase. A $10 \mathrm{mM}$ potassium dihydrogen orthophosphate solution was prepared by dissolving required quantity of salt in $1000 \mathrm{~mL}$ water and $\mathrm{pH}$ adjusted to 3.9 using triethylamine or dilute phosphoric acid. A $600 \mathrm{~mL}$ portion of this buffer was mixed with $400 \mathrm{~mL}$ of methanol $(60: 40 \mathrm{v} / \mathrm{v})$, shaken well and filtered using $0.45 \mu \mathrm{m}$ Nylon membrane filter. Hydrochloric acid $(\mathrm{HCl}, 2 \mathrm{M})$ and hydrogen peroxide $\left(\mathrm{H}_{2} \mathrm{O}_{2}, 5 \%\right)$ were prepared by appropriate dilution, and sodium hydroxide $(\mathrm{NaOH}, 2 \mathrm{M})$ was prepared by dissolving calculated amount of the chemical in water.

\section{Materials}

Working standard of GPZ was a generic gift from Bal Pharma, Bangalore, India. Dibizide- 5 and Glynase- 5 tablets each containing $5 \mathrm{mg}$ active content, were purchased from local market.

\section{Chromatographic conditions}

Analysis was isocratic at $0.8 \mathrm{mlmin}^{-1}$ flow rate with $10 \mathrm{mM}$ $\mathrm{KHPO}_{4}$ buffer: methanol (60:40) as mobile phase. The mobile phase was premixed, filtered through $0.2 \mu \mathrm{m}$ membrane filter to remove any particulate matter and degassed before use. Chromatographic separation was achieved on an Inertsil ODS $3 \mathrm{~V}(150 \mathrm{~mm} \times 4.6 \mathrm{~mm}$, $5 \mu \mathrm{m}$ particle size) column. The detector wavelength was set at $220 \mathrm{~nm}$ and the injection volume was $20 \mu \mathrm{L}$. The column temperature was maintained at $35^{\circ} \mathrm{C}$. Prior to injecting solutions, the column was equilibrated for at least $30 \mathrm{~min}$ with the mobile phase flowing through the system.

\section{Standard GPZ solution}

Accurately weighed 100mg of pure GPZ was dissolved in and diluted with the mobile phase to the mark in a $100 \mathrm{~mL}$ volumetric flask to get $1000 \mu \mathrm{gmL}^{-1} \mathrm{GPZ}$ stock solution.

\section{General procedures}

Procedure for bulk drug: Procedure for preparation of calibration curve: Working standard solutions containing 1-450 $\mu \mathrm{gmL}^{-1} \mathrm{GPZ}$ were prepared by serial dilution of stock solution. An aliquot of $20 \mu \mathrm{L}$ was injected (three injections) and eluted with the mobile phase under the stated chromatographic conditions. A plot of average peak area versus concentration was prepared. Alternatively, the regression equation was derived using mean peak area-concentration data and the concentration of the unknown was computed from the regression equation.

Procedure for tablets: Tablet powder equivalent to $100 \mathrm{mg}$ GPZ was transferred into a $100 \mathrm{~mL}$ calibrated flask containing $60 \mathrm{~mL}$ of mobile phase. The mixture was sonicated for $20 \mathrm{~min}$ to achieve complete dissolution of GPZ, and the content was then diluted to volume with the same solvent to yield a concentration of $1000 \mu \mathrm{gmL}$ ${ }^{1} \mathrm{GPZ}$, and filtered through a $0.2 \mu \mathrm{m}$ nylon membrane filter. The tablet extract was injected on to the HPLC column in replicates, after dilution to $300 \mu \mathrm{gmL}^{-1}$ level.

Procedure for placebo blank and synthetic mixture: A placebo blank was prepared by homogeneous mixing of hydroxyl cellulose (10mg), acacia (15mg), starch (10mg), sodium citrate (15mg), magnesium stearate $(15 \mathrm{mg})$, talc $(15 \mathrm{mg})$ and sodium alginate $(10 \mathrm{mg})$. A $100 \mathrm{mg}$ of the placebo blank was taken, its solution prepared as described under 'procedure for tablets', and then subjected to chromatography by following the general procedure. A synthetic mixture was prepared by homogeneous mixing of an accurately weighed $100 \mathrm{mg}$ of pure GPZ with $100 \mathrm{mg}$ of placebo. A solution of synthetic mixture equivalent to $1000 \mu \mathrm{gmL}^{-1} \mathrm{GPZ}$ was prepared as described under "procedure for tablets". The resulting solution was assayed $(n=5)$ by the proposed method after dilution to $300 \mu \mathrm{gmL}^{-1}$ GPZ with the mobile phase.

Procedure for stress study: A $3 \mathrm{~mL}$ aliquot of $1000 \mu \mathrm{gmL}^{-1} \mathrm{GPZ}$ solution was transferred into three different $10 \mathrm{~mL}$ calibrated flasks and added $2 \mathrm{ml}$ of $2 \mathrm{M} \mathrm{HCl}, 2 \mathrm{ml} 2 \mathrm{M} \mathrm{NaOH}$ or $2 \mathrm{ml} 5 \% \mathrm{H}_{2} \mathrm{O}_{2}$. The flasks 


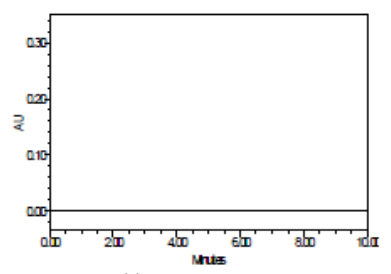

(a)

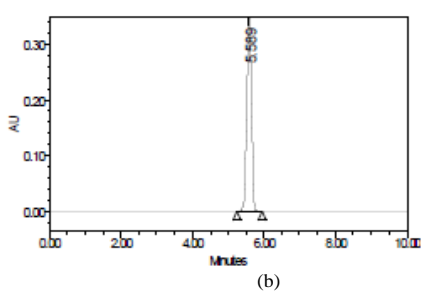

Figure 2: Chromatograms for: a) Blank (mobile phase) b) Pure GPZ solution $\left(300 \mu \mathrm{gmL}^{-1}\right)$.

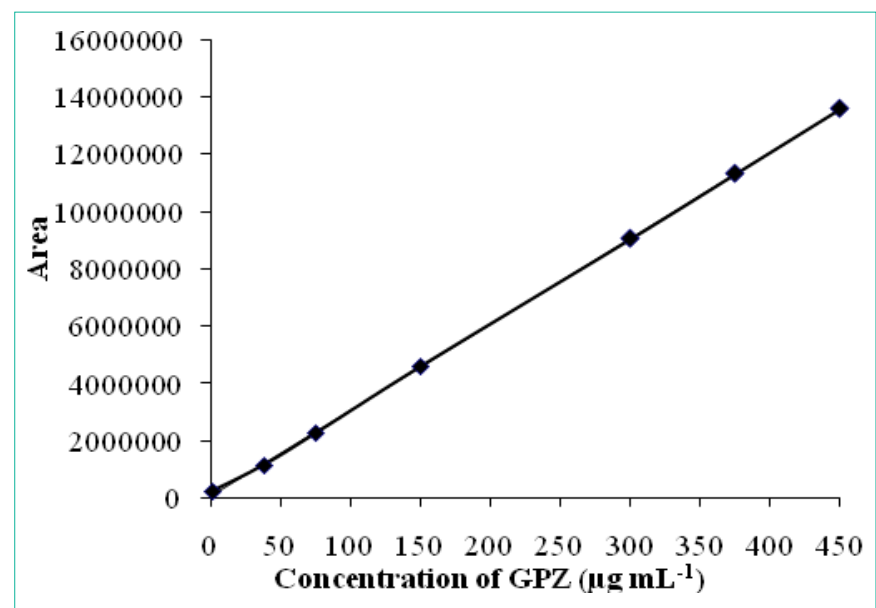

Figure 3: Calibration curve.

were placed in a water bath maintained at $80^{\circ} \mathrm{C}$ for $2 \mathrm{~h}$. After cooling to room temperature acid/base was neutralised with $2 \mathrm{ml} 2 \mathrm{M} \mathrm{NaOH}$ (acid hydrolysis) or $2 \mathrm{ml} 2 \mathrm{M} \mathrm{HCl}$ (base hydrolysis), and diluted to the mark with the mobile phase. Each solution was separately chromatographed. To study behaviour to heat, solid sample kept in a Petri Dish was placed in an oven at $100^{\circ} \mathrm{C}$ for $24 \mathrm{~h}$. For photodegradation, solid sample was exposed to uv radiation of wavelength $254 \mathrm{~nm}$ of $1200 \mathrm{~K}$ lux intensity flux for $48 \mathrm{~h}$ in an uv-chamber. Postexposure to heat and light, $300 \mu g m L^{-1}$ solutions were prepared separately in the mobile phase and chromatographed.

\section{Results and Discussion}

To obtain good linearity, sensitivity and selectivity, the method was optimized and validated in accordance with the current $\mathrm{ICH}$ guidelines [47]. The typical chromatograms obtained for blank and pure GPZ under optimized HPLC conditions are depicted in Figure 2.

\section{Method development}

A well defined symmetrical peak and satisfactory results were obtained upon measuring the response of eluent under the optimized conditions after thorough experimental trials that could be summarized as follows:

Choice of column: For performance characteristics, columns including Chromatopack $(250 \mathrm{~mm} \times 4.6 \mathrm{~mm}, 5 \mu \mathrm{m}$ particle size $)$; Hypersil BDS C8 $(250 \mathrm{~mm} \times 4.0 \mathrm{~mm}, 5.0 \mu \mathrm{m}$ particle size $)$ thermo; Inertsil ODS $3 \mathrm{~V}(250 \mathrm{~mm} \times 4.0 \mathrm{~mm}, 5.0 \mu \mathrm{m}$ particle size $)$; Luna C18 $(250 \mathrm{~mm} \times 4.0 \mathrm{~mm}, 5.0 \mu \mathrm{m}$ particle size $)$ and Zorbax XDB $(250 \mathrm{~mm}$ $\times 4.0 \mathrm{~mm}, 5.0 \mu \mathrm{m}$ particle size) were tried. The results revealed that the Inertsil ODS 3V column was more suitable since it gave better sensitivity.

Choice of wavelength: The UV detector response of GPZ was studied and the best wavelength was found to be $220 \mathrm{~nm}$ showing the highest sensitivity.

Mobile phase composition: Several modifications in the mobile phase composition were tried to obtain a symmetrical peak with a reasonable retention time. These modifications included type and proportion of the organic modifier, $\mathrm{pH}$, strength of the phosphate buffer, and flow rate. The results shown in Table 1 reveal that highest number of theoretical plates resulted when the mobile phase consisted of phosphate buffer ( $\mathrm{pH} 3.9$ adjusted with $0.1 \% \mathrm{H}_{3} \mathrm{PO}_{4}$ ) and methanol in the ratio of $60: 40$ and pumped at a flow rate of $0.8 \mathrm{mlmin}^{-1}$. Of several organic modifiers tried, methanol was found to give an elegent and highly sensitive peak.

Ratio of organic modifier: The effect of proportion of organic modifier on the sensitivity and retention time was investigated using mobile phases containing up to $30-60 \%$ methanol. Table 1 shows that $40 \%$ methanol was the best, giving well defined peak and the highest number of theoretical plates.

Effect of $\mathrm{pH}$ and ionic strength of buffer: The effect of $\mathrm{pH}$ of the mobile phase on the sensitivity and retention timeof the test solute was investigated using mobile phases of $\mathrm{pH}$ ranging from 2.0-4.5. The results (Table 1) revealed that $\mathrm{pH} 3.9$ was the most appropriate, giving well defined peak and the highest number of theoretical plates. At lowerand higher $\mathrm{pH}$, non-symmetrical peak and smaller number of theoretical plateswere obtained. Therefore $\mathrm{pH} 3.9$ was fixed as optimum. The same trend wasobserved after making alteration in the ionic strength of the buffer and $10 \mathrm{mM}$ phosphate buffer was used as working buffer throughout the investigation.

The effect of flow rate: The effect of flow rate on the symmetry, sensitivity and retention time ofthe peak was studied, and a flow rate of $0.8 \mathrm{mLmin}^{-1}$ was optimal for bettersymmetry and reasonable retention time as shown in Table 1.

\section{Method validation}

Linearity: To study the linearity, standard solutions in the range 1 to $450 \mu \mathrm{gmL}^{-1} \mathrm{GPZ}$ were chromate graphed in triplicate and mean peak area for each standard calculated. A calibration graph was prepared by plotting mean peakarea against concentration, and linear relationship was established by least-square regression analysis. The calibration plot was linear over the concentration range, $1-450 \mu \mathrm{g}$ $\mathrm{mL}^{-1}(\mathrm{n}=3)$ (Figure 3 ) and can be described by the equation:

Table 1: Effect of ratio of buffer to organic modifier, $\mathrm{pH}$ and ionic strength of buffer, and mobile phase flow rate on the number of theoretical plates.

\begin{tabular}{|c|c|c|c|c|c|c|c|}
\hline $\begin{array}{c}\text { Ratio } \\
(\mathrm{A} / \mathrm{B})^{\mathrm{a}}\end{array}$ & $\begin{array}{c}\text { Number } \\
\text { of } \\
\text { theoretical } \\
\text { plates (N) }\end{array}$ & $\begin{array}{c}\mathrm{pH} \text { of } \\
\text { the } \\
\text { medium }\end{array}$ & $\begin{array}{c}\text { Number } \\
\text { of } \\
\text { theoretical } \\
\text { plates (N) }\end{array}$ & $\begin{array}{c}\% \\
\mathrm{H}_{3} \mathrm{PO}_{4}\end{array}$ & $\begin{array}{c}\text { Number } \\
\text { of } \\
\text { theoretical } \\
\text { plates (N) }\end{array}$ & $\begin{array}{c}\text { Flow } \\
\text { rate, } \\
\mathrm{mL} \\
\text { min }^{-1}\end{array}$ & $\begin{array}{c}\text { Number } \\
\text { of } \\
\text { theoretical } \\
\text { plates (N) }\end{array}$ \\
\hline $40 / 60$ & 4934 & 2.0 & 5789 & 0.050 & 8537 & 0.50 & 6176 \\
$50 / 50$ & 6588 & 2.5 & 7866 & 0.075 & 9649 & 0.60 & 7648 \\
$55 / 45$ & 7693 & 3.0 & 8679 & 0.100 & 9987 & 0.70 & 8765 \\
$60 / 40$ & 9261 & 3.9 & 9956 & 0.125 & 9657 & 0.80 & 9960 \\
$70 / 30$ & 8756 & 4.1 & 9867 & 0.150 & 8586 & 0.90 & 9768 \\
- & - & 4.3 & 8954 & 0.200 & 8246 & 1.00 & 9326 \\
- & - & 4.5 & 5724 & 0.250 & 8097 & 1.20 & 8976 \\
\hline
\end{tabular}

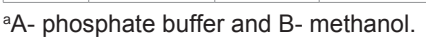


Table 2: Linearity and regression parameters.

\begin{tabular}{|c|c|c|c|c|c|c|c|c|}
\hline \multicolumn{7}{|c|}{ Parameter } & \multicolumn{2}{|c|}{ Value } \\
\hline \multicolumn{7}{|c|}{ Linear range, $\mu \mathrm{gmL}^{-1}$} & \multicolumn{2}{|c|}{$1-450$} \\
\hline \multicolumn{7}{|c|}{ Limits of detection, (LOD), $\mu \mathrm{gmL}^{-1}$} & \multicolumn{2}{|c|}{0.03} \\
\hline \multicolumn{7}{|c|}{ Limits of quantification, (LOQ), $\mu \mathrm{gmL}^{-1}$} & \multicolumn{2}{|c|}{0.09} \\
\hline \multicolumn{9}{|c|}{ Regression equation, $\mathrm{y}^{*}$} \\
\hline \multicolumn{7}{|l|}{ Slope (m) } & \multicolumn{2}{|c|}{29955} \\
\hline \multicolumn{7}{|c|}{ Intercept (b) } & \multicolumn{2}{|c|}{86386} \\
\hline \multicolumn{7}{|c|}{ Standard deviation of intercept (Sb) } & \multicolumn{2}{|c|}{897.9} \\
\hline \multicolumn{7}{|c|}{ Standard deviation of slope (Sm) } & \multicolumn{2}{|c|}{1681.2} \\
\hline Correlatio & n coefficient & & & & & & \multicolumn{2}{|c|}{0.9999} \\
\hline \multicolumn{9}{|c|}{$\begin{array}{l}{ }^{*} y=m x+b, \text { where } y \text { is the mean peak area, } x \text { concentration in } \mu \mathrm{g} \mathrm{mL}^{-1}, b \text { intercept } \\
m \text { slope. }\end{array}$} \\
\hline \multicolumn{9}{|c|}{ Table 3: Results of accuracy and precision study $(n=5)$. } \\
\hline \multirow{2}{*}{$\begin{array}{c}\mathrm{GPZ} \\
\text { injected, } \\
\mu \mathrm{g} \mathrm{mL} \mathrm{m}^{-1}\end{array}$} & \multicolumn{4}{|c|}{ Intra-day } & \multicolumn{4}{|c|}{ Inter-day } \\
\hline & $\begin{array}{l}\text { GPZ found, } \\
\mu g \mathrm{~mL}^{-1}\end{array}$ & $\begin{array}{c}\% \\
\mathrm{RE}^{\mathrm{a}}\end{array}$ & $\begin{array}{c}\% \\
\text { RSD }^{\mathrm{b}}\end{array}$ & $\begin{array}{c}\% \\
\mathrm{RSD}^{\mathrm{c}}\end{array}$ & $\begin{array}{c}\text { GPZ found, } \\
\mu \mathrm{g} \mathrm{mL} L^{-1}\end{array}$ & $\begin{array}{c}\% \\
\mathrm{RE}^{\mathrm{a}}\end{array}$ & \begin{tabular}{|c|}
$\%$ \\
RSD $^{\mathrm{b}}$
\end{tabular} & $\begin{array}{c}\% \\
\text { RSD }^{\mathrm{c}}\end{array}$ \\
\hline 150 & 151.8 & 1.20 & 0.63 & 0.59 & 152.1 & 1.40 & 0.49 & 0.27 \\
\hline 300 & 298.7 & 0.43 & 0.45 & 0.36 & 297.5 & 0.83 & 0.34 & 0.31 \\
\hline 450 & 448.2 & 0.40 & 0.54 & 0.47 & 452.7 & 0.60 & 0.61 & 0.9 \\
\hline
\end{tabular}

${ }^{a}$ Relative error; ${ }^{b}$ Relative standard deviation based on peak area; ${ }^{\mathrm{c}}$ Relative standard deviation based on retention time.

$$
\mathrm{y}=\mathrm{mx}+\mathrm{b}
$$

where $y$ the mean peak area, $x$ the concentration of GPZ in $\mu \mathrm{gmL}^{-1}, \mathrm{~m}$ slope and b intercept. The slope $(\mathrm{m}), \mathrm{y}$-intercept $(\mathrm{b})$ and theirstandard deviations were evaluated and are presented in Table 2. These results confirm the linear relationship between peak area and concentration aswell as the sensitivity of the method.

Limits of quantification (LOQ) and detection (LOD): The limit of quantification (LOQ) was determined by establishing the lowest concentration that can be measured according to $\mathrm{ICH}$ recommendations [47], below which the calibration graph is non linear and was found to be $0.09 \mu \mathrm{gmL}^{-1}$. The limit of detection (LOD) was determined by establishing the minimum level at which the analyte can be reliably detected and it was found to be $0.03 \mu \mathrm{gmL}^{-1}$.

Precision and accuracy: Both repeatability (within-day precision) and reproducibility (between-day precision) was determined as follows:

Pure drug solution at three concentration levels (within the linear range) were prepared and injected in seven replicates during the same day for repeatability, and over a period of five days (five injections

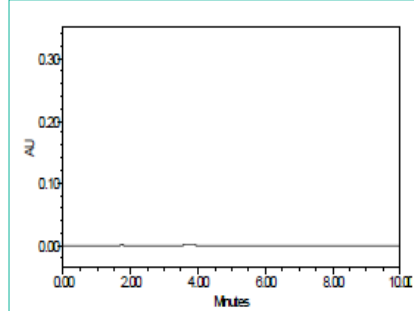

(a)

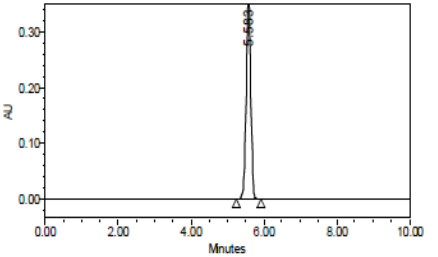

(b)
Figure 4: Chromatograms obtained for: a) placebo blank and b) tablet extract (300 $\left.\mathrm{gmL}^{-1} \mathrm{GPZ}\right)$.

per day) for reproducibility. Percent RSD and \%RE were calculated to judge the precision and accuracy. The results of this study compiled in Table 3 speak of excellent precision and accuracy of the proposed method.

Method robustness: The robustness of the method was evaluated by making small but deliberate changes in the chromatographic conditions. The chromatographic conditions varied were: flow rate (0.8 and $0.8 \pm 0.1 \mathrm{~mL}$ ), wavelength (220 and $220 \pm 1 \mathrm{~nm}$ ), temperature ( 35 and $35 \pm 2{ }^{\circ} \mathrm{C}$ ) and mobile phase composition (60 and $60 \pm 5 \%$ buffer: 40 and $40 \pm 5 \%$ methanol). These slight alterations did not significantly affect the system suitability parameters: retention time, tailing factor and number of theoretical plates as indicated by low values of \%RSD (Table 4) (measure of intermediate precision).

\section{Method ruggedness}

The ruggedness of the method was assessed by comparison of the results for the assay of GPZ performed by three analysts in the same laboratory. The inter-personal RSD did not exceed $1.07 \%$ indicating the ruggedness of the method (Table 5).

\section{Selectivity}

Selectivity of the method was evaluated by injecting the mobile phase, placebo blank, pure drug solution and tablet extract. No peaks were observed for mobile phase and placebo blank, and no extra peaks were observed for tablet extract (Figure 4). Synthetic mixture solution, when analysed at $300 \mu \mathrm{gmL}^{-1}$ concentration level, yielded percent recoveries of $97.36 \pm 1.2$ indicating the absence of interference from the tablet excipients.

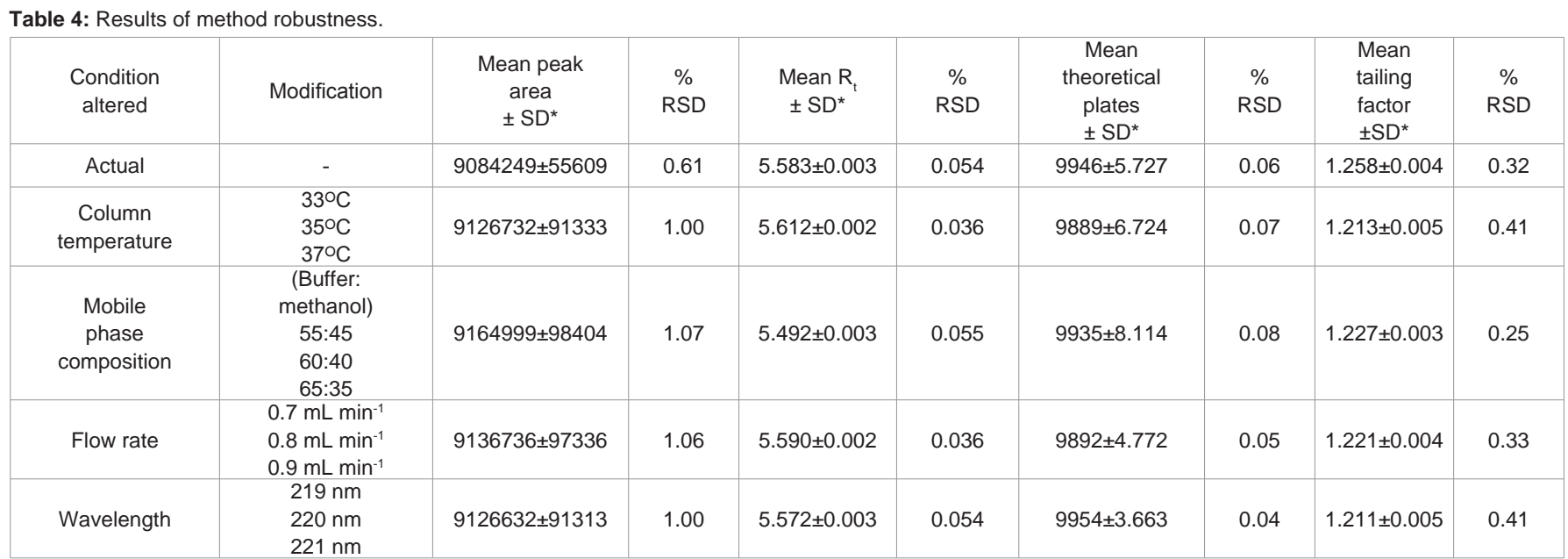

*Mean value of three determinations at GPZ concentration of $300 \mu \mathrm{gmL}^{-1}$. 
Table 5: Results of method ruggedness $(n=3)$.

Table 5: Results of method ruggedness $(\mathrm{n}=3)$.
\begin{tabular}{|c|c|c|c|c|c|c|}
\hline Variable & $\begin{array}{c}\text { Mean } \\
\text { Peak } \\
\text { area } \pm \mathrm{SD}^{*}\end{array}$ & \%RSD & $\begin{array}{c}\text { Mean } \\
\mathrm{Rt} \pm \mathrm{SD}^{*}\end{array}$ & \%RSD & $\begin{array}{c}\text { Mean } \\
\text { theoretical } \\
\text { plates } \pm S D\end{array}$ & $\begin{array}{c}\text { Mean } \\
\text { tailing } \\
\text { factor } \pm \\
\text { SD* }\end{array}$ \\
\hline $\begin{array}{c}\text { Analysts } \\
(\mathrm{n}=3)\end{array}$ & $9164999 \pm 98404$ & 1.07 & $5.592 \pm 0.003$ & 0.054 & $9899 \pm 7.614$ & 0.08 \\
\hline
\end{tabular}

*Mean value of three determinations at GPZ concentration of $300 \mu \mathrm{gmL}^{-1}$.

Table 6: Results of solution stability.

\begin{tabular}{|c|c|c|c|c|c|c|c|c|}
\hline Time, $\mathrm{h}$ & $\begin{array}{c}\text { Mean } \\
\text { Peak } \\
\text { area } \pm S D^{*}\end{array}$ & Pooled \%RSD & $\begin{array}{c}\text { Mean } \\
\mathrm{Rt} \pm S D^{*}\end{array}$ & Pooled \%RSD & $\begin{array}{l}\text { Mean } \\
\text { theoretical } \\
\text { plates } \pm S D\end{array}$ & Pooled \%RSD & $\begin{array}{c}\text { Mean } \\
\text { tailing } \\
\text { factor } \pm S D^{*}\end{array}$ & Pooled \%RSD \\
\hline 0 & $9084249 \pm 55609$ & \multirow{3}{*}{0.92} & $5.592 \pm 0.002$ & \multirow{3}{*}{0.04} & $9885 \pm 8.565$ & \multirow{3}{*}{0.10} & $1.258 \pm 0.004$ & \multirow{3}{*}{0.33} \\
\hline 12 & $9126732 \pm 91333$ & & $5.581 \pm 0.002$ & & $9989 \pm 9.774$ & & $1.213 \pm 0.005$ & \\
\hline 24 & $9164999 \pm 98404$ & & $5.603 \pm 0.003$ & & $9835 \pm 9.524$ & & $1.227 \pm 0.003$ & \\
\hline
\end{tabular}

*Mean value of three determinations for GPZ concentration of $300 \mu \mathrm{gmL}^{-1}$ at each time interval.

Table 7: Results of determination of GPZ in tablet and statistical comparison with the reference method.

\begin{tabular}{|c|c|c|c|c|c|}
\hline \multirow{2}{*}{$\begin{array}{l}\text { Tablet } \\
\text { brand } \\
\text { name }\end{array}$} & \multirow{2}{*}{$\begin{array}{c}\text { Nominal } \\
\text { amount, } \\
\text { mg }\end{array}$} & \multicolumn{2}{|c|}{ NTG found ${ }^{*}(\%) \pm$ SD } & \multirow{2}{*}{ t-value } & \multirow{2}{*}{ F- value } \\
\hline & & $\begin{array}{l}\text { Reference } \\
\text { method }\end{array}$ & $\begin{array}{l}\text { Proposed } \\
\text { method }\end{array}$ & & \\
\hline Dibizide & 5 & $98.67 \pm 0.87$ & $99.48 \pm 0.56$ & 1.75 & 2.41 \\
\hline Glynase & 5 & $99.45 \pm 1.10$ & $100.5 \pm 0.42$ & 1.61 & 1.34 \\
\hline
\end{tabular}

"Mean value of five determinations. Tabulated t-value at $95 \%$ confidence level is 2.77; Tabulated F-value at $95 \%$ confidence level is 6.39

Table 8: Results of recovery study by standard addition method.

\begin{tabular}{|c|c|c|c|c|}
$\begin{array}{c}\text { Tablet } \\
\text { studied }\end{array}$ & $\begin{array}{c}\text { NTG in } \\
\text { tablet, } \\
\mu \mathrm{g} \mathrm{mL}^{-1}\end{array}$ & $\begin{array}{c}\text { Pure NTG } \\
\text { added, } \\
\mu \mathrm{g} \mathrm{mL}^{-1}\end{array}$ & $\begin{array}{c}\text { Total } \\
\text { found, } \\
\mu \mathrm{g} \mathrm{mL}^{-1}\end{array}$ & $\begin{array}{c}\text { Pure NTG } \\
\text { recovered } \\
(\% \mathrm{NTG} \pm \mathrm{SD})\end{array}$ \\
\hline \multirow{3}{*}{ Dibizide } & 99.48 & 50 & 150.2 & $100.5 \pm 0.97$ \\
& 99.48 & 100 & 198.7 & $99.63 \pm 0.87$ \\
& 99.48 & 150 & 252.5 & $101.2 \pm 1.05$ \\
\hline \multirow{3}{*}{ Glynase } & 100.5 & 50 & 148.6 & $98.75 \pm 0.67$ \\
& 100.5 & 100 & 199.5 & $99.49 \pm 0.65$ \\
& 100.5 & 150 & 251.5 & $100.4 \pm 0.90$ \\
\hline
\end{tabular}

*Mean value of three determinations.

\section{Solution stability}

The drug solution was injected at different time intervals of 0,12 and $24 \mathrm{~h}$, and chromatograms were recorded. At the specified time interval, \%RSD value for peak area, retention time and number of theoretical plates was calculated, and subsequently pooled \%RSD was computed. This value, which is $<1 \%$ (Table 6 ), amply demonstrates that the crucial system suitability parameters remained unaltered indicating the stability of the solution over a period of $24 \mathrm{~h}$.

\section{Application to tablets}

The developed method was applied to the determination of GPZ in two brands of tablets containing 5mg GPZ per tablet. Quantification was performed using the regression equation. The same tablet powder was used for assay by official method (20) for comparison. The results were compared statistically by applying the Student's test for accuracy and F-test for precision. As shown by the results compiled in Table 7, the calculated t-test and F-values did not exceed the tabulated values of 2.77 and 6.39 for four degrees of freedom at the $95 \%$ confidence level, suggesting that the proposed method and the reference method do not differ significantly with respect to accuracy and precision.

\section{Accuracy by recovery test}

The accuracy of the proposed method was further checked by performing recovery test. Pre-analyzed tablet powder was spiked
Table 9: Results of degradation study.

\begin{tabular}{|c|c|}
\hline Degradation condition & $\%$ Degradation \\
\hline Acid hydrolysis $\left(2 \mathrm{M} \mathrm{HCl}, 80^{\circ} \mathrm{C}, 2 \mathrm{~h}\right)$ & No degradation \\
\hline Base hydrolysis $\left(2 \mathrm{M} \mathrm{NaOH}, 80^{\circ} \mathrm{C}, 2 \mathrm{~h}\right)$ & No degradation \\
\hline Oxidation $\left(5 \% \mathrm{H}_{2} \mathrm{O}_{2}, 80^{\circ} \mathrm{C}, 2 \mathrm{~h}\right)$ & $60.9 \%$ \\
\hline Thermal $\left(105^{\circ} \mathrm{C}, 3\right.$ hours $)$ & No degradation \\
\hline Photolytic $(1.2$ million lux hours $)$ & No degradation \\
\hline
\end{tabular}

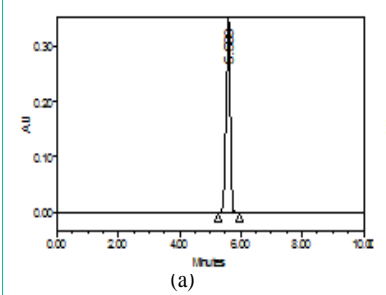

(a)

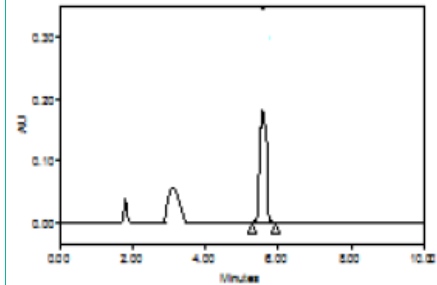

(c)

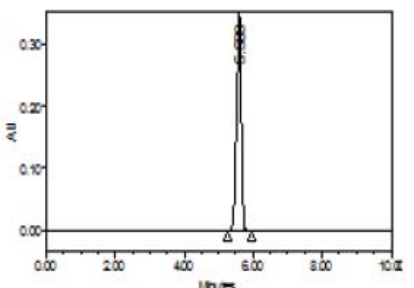

(e)

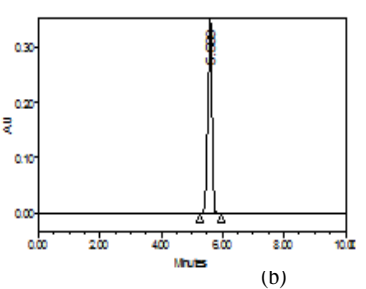

(d)

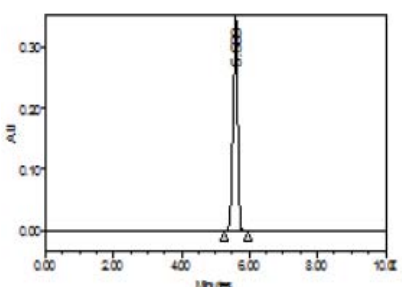

Figure 5: Chromatograms of GPZ $\left(300 \mu \mathrm{gmL}^{-1}\right)$ after forced degradation: a) acid degradation; b) base degradation; c) peroxide degradation; d) thermal degradation and e) photolytic degradation.

with pure GPZ at three different concentration levels and the total was determined by the proposed method. Each determination was repeated three times. The recovery of pure drug added was quantitative (Table 8) and revealed that co-formulated substances did not interfere in the determination. 


\section{Results of forced degradation study}

All forced degradation experiments were performed at $300 \mu \mathrm{gmL}$ ${ }^{1}$ concentration level. The inference with regard vulnerability to degradation was based on the comparison of the chromatograms recorded post-degradation with those obtained under optimized chromatographic conditions. GPZ was found to be more stable under photolytic and thermal stress conditions in solid state. The drug was also stable towards acid and base hydrolysis at elevated temperature. The drug degraded up to $60.9 \%$ under oxidative stress condition. The chromatograms obtained for GPZ after subjecting to forced degradation are presented in Figure 5. The results of this study are given in Table 9.

\section{Conclusions}

This is the first article describing the stability-indicating reversed phase HPLC determination of glipizide in pharmaceutical samples whenever it is present alone. The method has been determined to be a good alternative to several HPLC methods reported earlier with respect to linear range and sensitivity. Shorter run time $(<10 \mathrm{~min})$ and low flow rate $\left(0.8 \mathrm{mlmin}^{-1}\right)$ make the method cost-effective interms of overall analysis time and consumption of mobile phase. The method has been shown to be both precise and accurate, besides being both robust and rugged, and may be useful in routine analysis.

\section{Acknowledgement}

Authors thank Bal Pharma, Bangalore, India, for gifting glipizide pure sample. Prof. K. Basavaiah gratefully acknowledges the financial assistance by UGC, New Delhi, India, in the form of BSR Faculty fellowship.

\section{References}

1. Sweetman SC. Martindale: The Complete Drug Reference, $34^{\text {th }} \mathrm{Ed}$. Pharmaceutical Press, London, 2005; 5083.

2. Brogden RN, Heel RC, Pakes GE, and Speight TM. Glipizide: a review of its pharmacological properties and therapeutic use. Drugs. 1979; 18: 329-353.

3. Haakan E. High-performance liquid chromatographic determination of glipizide in human plasma and urine. J. Chromatogr B: Biomed. Sci. App. 1987; 421: 319-326.

4. Lakshmi KS and Rajesh T. Separation and Quantification of Eight Antidiabetic Drugs on A High-Performance Liquid Chromatography: Its Application to Human Plasma Assay. ISRN pharmaceutics. 2011; 2011: 1-7.

5. Rahila SJ, Manisha PP, Prabha MR, Asif K and Pramod YG. Sensitive and selective analytical method for the quantification of glipizide in human plasma Int. Res. J. Pharm. 2010; 1: 378-383.

6. Swaroop LR, Prashanth PK, Ashish HA and Rajesh NB. Development and validation of RP-HPLC method for analysis of glipizide in guinea pig plasma and its application to pharmacokinetic study. Int. J. Pharm Tech Res. 2010; 2: 1649-1654.

7. Emilsson $\mathrm{H}$. High-performance liquid chromatographic determination of glipizide in human plasma and urine. J. Chromatogr. 1987; 421: 319-326.

8. Bae JW, Kim NT, Choi C, Kim MJ, Jang CG and Lee SY. HPLC analysis of plasma glipizide and its application to pharmacokinetic study. J. Liquid Chromatogr. Rel. Tech. 2009; 32: 1969-1977.

9. Venkatesh $\mathrm{P}$, Harisudhan $\mathrm{T}$, Choudhury $\mathrm{H}$, Mullangi $\mathrm{R}$ and Srinivas NR. Simultaneous estimation of six anti-diabetic drugs--glibenclamide, gliclazide, glipizide, pioglitazone, repaglinide and rosiglitazone: development of a nove HPLC method for use in the analysis of pharmaceutical formulations and its application to human plasma assay. Biomed. Chromatogr. 2006; 20: 1043 1048
10. Aburuz S, Millership J and McElnay J. The development and validation of liquid chromatography method for the simultaneous determination of metformin and glipizide, gliclazide, glibenclamide or glimperide in plasma. J Chromatogr B: Anal. Tech. Biomed. Life Sci. 2005; 817: 277-286.

11. Yang L, Lijuan H, Jide W, Chunrui D, Shiru X, Feng S, et al. Simultaneous determination of three diabetic drugs in urine by high performance liquid chromatography. Fenxi Ceshi Xuebao. 2011; 30: 293-297.

12. Ning L, Ying D, Feng $Q$, Jia $Y$ and Famei L. A rapid and reliable UPLCMS/MS method for the identification and quantification of fourteen synthetic anti-diabetic drugs in adulterated Chinese proprietary medicines and dietary supplements. Biomed. Chromatogr. 2010; 24: 1255-1261.

13. Atif M, Khalid SH, Onn GLK, Sulaiman SA, Asif M and Chandrasekaran A. Development and validation of RP-HPLC-UV method for the determination of Glipizide in human plasma. J. Young Pharm. 2013; 5: 26-29.

14. Li N, Deng Y, Qin F, Yu J and Li F. Simultaneous quantification of metformin and glipizide in human plasma by high-performance liquid chromatographytandem mass spectrometry and its application to a pharmacokinetic study. Biomed. Chromatogr. 2013; 27: 191-196.

15. Ding CG, Zhou Z, Ge QH, Zhi XJ and Ma LL. Simultaneous determination of metformin and glipizide in human plasma by liquid chromatography-tandem mass spectrometry. Biomed. Chromatogr. 2007; 21: 132-138.

16. Lin ZJ, Krieger DD and Shum L. Simultaneous determination of glipizide and rosiglitazone unbound drug concentrations in plasma by equilibrium dialysis and liquid chromatography-tandem mass spectrometry. J. Chromatogr B: Anal. Tech. Biomed. Life Sci. 2004; 801: 265-272.

17. Qiu X, Zheng S, Wang Y, Wang R and Ye L. A rapid and simple UPLC-MSMS method for determination of glipizide in human plasma and its application to bioequivalence study. J. Chromatogr. Sci. 2015; 53: 85-89.

18. Ying ZC, Ling XJ, Guo LZ and Qiang LN. UPLC/MS/MS determination of glyburide and glipizide added in traditional Chinese medicinal preparation. Chinese J. Pharm. Anal. 2008; 28: 326-328.

19. Maggi E, Pianezzola P and Valzelli G. Radioimmunoassay of glipizide in human plasma. European J. Clin. Pharm. 1981; 21: 251-255.

20. European Pharmacopoea 6.0, Official Monograph 01/2008:0906, p. 1977.

21. Aruna A and Nancey K. Simultaneous estimation of metformin HCL and glipizide in solid dosage forms by ultraviolet spectrophotometry. Indian Drugs. 2000; 37: 533-536.

22. Chungath TT, Reddy YP and Devanna N. Simultaneous spectrophotometric estimation of metformin hydrochloride and glipizide in tablet dosage forms. Int. J. Pharm Tech Res. 2011; 3: 2064-2067.

23. Sarangi RR, Panda SN, Panda SK and Sahu KC. Simultaneous UVSpectrophotometric Estimation of Glipizide and Metformin in Bulk and Its Dosage Form. Int. J. Pharm. Biol. Arch. 2011; 2: 1137-1145.

24. Adhikari L, Jagadev S, Sahoo S, Murthy PN and Mishra US. Devlopement and validation of UV-visible spectrophotometric method for simultaneous determination of pioglitazone hydrochloride, metformin hydrochloride and glipizide in its bulk and pharmaceutical dosage form. Int. J. Chem Tech Res. 2012; 4: 625-630

25. Trivedi HK, Kshtri N, Patel V and Roa V. Development and validation of an UPLC method for in-vitro study of glipizide extended release tablets. Int. J. Pharm. Sci. Res. 2012; 3: 3317-3322.

26. Cijo MX, Basavaiah K, Vinay KB and Swamy N. Quality by design approach for the development and validation of glipizide, an antidiabetic drug, by RPUPLC with application to formulated forms and urine. ISRN Chromatography. 2013; 2013 Article ID 738397: 1-10.

27. El Kousy NM. Stability-indicating densitometric determination of some antidiabetic drugs in dosage forms, using TLC. Microchim. Acta. 1998; 128 : 65-68.

28. Gumienicze A, and Berecka A. Quantitative analysis of gliclazide and glipizide in tablets by a new validated and stability-indicating RPTLC method. J. Planar Chromatogr. Modern TLC. 2010; 23: 129-133. 
29. Modi DK and Patel BH. Simultaneous determination of metformin hydrochloride and glipizide in tablet formulation by HPTLC. J. Liq. Chromatogr. Rel. Tech. 2012; 35: 28-39.

30. Ghoneim EM, El-Attar MA, Hammam E and Khashaba PY. Stripping voltammetric quantification of the anti-diabetic drug glipizide in bulk form and pharmaceutical formulation. J. Pharm. Biomed. Anal. 2007; 43: 1465-1469.

31. Vijaya SS, Satya KV, Hima BV and Devala RG. High pressure liquid chromatography estimation of glipizide in pharmaceutical dosage forms. Asian J. Chem. 2006; 18: 1309-1312.

32. Mantri MA and Shanmukhappa S. A validated RP-HPLC method fo estimation of glipizide in its pure and pharmaceutical dosage form (tablets). Material Science Research India. 2009; 6: 223.

33. Rahila S and Asif K. Reverse phase high performance liquid chromatographic method for the analysis of glipizide in pharmaceutical dosage forms. Int. J. Res. Ayur. Pharm. 2010; 1: 455-458.

34. Rayanam VI, Rao LA and Ramana MV. Development and validation of LC method for the estimation of glipizide in pharmaceutical dosage form and serum. Int. J. Res. Pharm. Chem. 2011; 1: 50-54

35. Liping $H$, Yan $X$, Jiaxiu $H$, Jingping $S$, Jiali $Z$, Jin $Z$, et al. Determination of glipizide in sustained release tablets by RP-HPLC. Zhonghua Yixue Yanjiu Zazhi. 2011; 11: 337-339.

36. Najma S, Arayne SM, Nadir AS and Hashim ZM. Simultaneous determination of glipizide and glimepride by Rp-Hplc in dosage formulations and in human serum. Med. Chem. Res. 2012; 21: 2443-2448.

37. Jing F, Jia L, Dan S, Hua DR, Shun BK and Hui CX. Determination of two components in metformin and glipizide tablets by reversed-phase ion-pair HPLC. Chinese J. New Drugs Clin. Rem. 2010; 29: 445-447.

38. Anurag D and Shukla IC. Simultaneous determination of glipizide and metformin hydrochloride in pharmaceutical preparation by HPLC. J. Indian Chem. Soc. 2004; 81: 84-86.

39. Rao BU and Nikalje AP. Determination of glipizide, glibenlamide and glimeperide in a tablet dosage form in the presence of metformin hydrochloride by ion pair -reversed phase liquid chromatographic technique. J. Anal. Bioanal. Tech. 2010; 1: 1-5.

40. Bhavana K and Srinivas M. RP-HPLC method for the simultaneous estimation of glipizide and simvastatin in bulk and in a synthetic mixture. Inv. Imp. Pharm. Anal. Quality Assur. 2015; 2015: 19-25.

41. Anna G, Anna B and Lukasz K. Stability-indicating validated HPLC method for simultaneous determination of oral antidiabetic drugs from thiazolidinedione and sulfonylurea groups in combined dosage forms. J. AOAC Int. 2010; 93: 1086-1092.

42. Lakshmi KS and Rajesh T. Development and validation of RP-HPLC method for simultaneous determination of glipizide, rosiglitazone, pioglitazone, glibenclamide and glimepiride in pharmaceutical dosage forms and human plasma. J. Iranian Chem. Soc. 2011; 8: 31-37.

43. Reddy MU, Reddy PV, Somasekhar P and Varaprasad B. Single and high resolution RP-HPLC method for the determination of six anti diabetic drug products. J. Pharm. Res. 2011; 4: 1209-1212.

44. Meng $L$ and Subi L. Ion-pair HPLC determation of anti-diabetic agents in traditional Chinese medicines and health care products. Chinese J. Pharm. Anal. 2010; 30: 1038-1041.

45. ICH Harmonized tripartite guideline Q1A (R2), Stability testing of new drug substances and products, Geneva, February, 2003.

46. International Conference on Hormonisation of Technical Requirements for Registration of Pharmaceuticals for Human Use, Stability Testing: Photostability Testing of New Drug Substances and Products, Q1B November, 1996

47. International Conference on Hormonisation of Technical Requirements for Registration of Pharmaceuticals for Human Use, ICH Harmonised Tripartite Guideline, Validation of Analytical Procedures: Text and Methodology Q2 (R1), Complementary Guideline on Methodology dated 06 November 1996, incorporated in November 2005, London. UK.
Austin J Anal Pharm Chem - Volume 4 Issue 1 - 2017 ISSN : 2381-8913 | www.austinpublishinggroup.com Basavaiah et al. (c) All rights are reserved
Citation: Basavaiah K and Rajendraprasad N. Rapid and Reliable Determination of Glipizide in Pharmaceutical Samples by HPLC and Its Degradation Study. Austin J Anal Pharm Chem. 2017; 4(1): 1080. 